\title{
Union Wage Effects in the \\ Presence of Enterprise Bargaining*
}

\author{
Mark Wooden \\ Melbourne Institute of Applied Economic and Social Research \\ The University of Melbourne
}

Melbourne Institute Working Paper No. 7/00

ISSN 1328-4991

ISBN 0734014872

April 2000

* The data used in this article were collected by the Department of Employment, Workplace Relations and Small Business, and supplied to the author through the Australian National University Social Science Data Archives. Thanks are also owed to Jeff Borland, Keith Hancock, and two anonymous referees for helpful comments.

Melbourne Institute of Applied Economic and Social Research

The University of Melbourne

Victoria 3010 Australia

Telephone (03) 83445330

Fax (03) 83445630

Email melb.inst@iaesr.unimelb.edu.au

WWW Address http://www.ecom.unimelb.edu.au/iaesrwww/home.html 


\begin{abstract}
Previous research on union wage effects has underestimated the potential for unions to raise member wages since the data used do not enable differences across bargaining units to be properly accounted for. This study addresses this deficiency by utilising matched employeremployee data which permit workplace-specific union wage effects to be identified. Results from the estimation of wage equations indicate that while there is only a very small intraworkplace union wage effect, differences across workplaces are considerable. This differential, however, only exists at workplaces where there is substantial coverage by collective agreements.
\end{abstract}




\section{Introduction}

In a relatively recent article, Miller and Mulvey (1996) reported evidence indicating that relative union wage effects in Australia are small, with the union-nonunion wage differential estimated to be just 2.6 per cent for men and 1.6 per cent for women. Moreover, given other evidence that union members are treated preferentially in terms of access to overtime, Miller and Mulvey concluded that it may be 'questionable as to whether there exists any union relative wage effect at all' (p. 149). Such conclusions appear to be at odds with those reached in most earlier studies using Australian data (e.g., Mulvey, 1986; Crockett and Hall, 1987; Miller and Rummery, 1989; Blanchflower and Freeman, 1992; Christie, 1992; Kornfeld, 1993), which have reported union wage differentials ranging from 5 to 15 per cent. Miller and Mulvey (1996) argued that such large differentials were difficult to accept given the systems of industrial awards that existed in Australia ensured that increases in award wages applied to all employees covered by those awards, irrespective of whether they were members of a trade union or not. They contended that the larger differentials reported in the earlier studies were the result of omitted variables bias, and specifically, the failure to adequately control for workplace size. ${ }^{1}$

Miller and Mulvey (1996), however, made no comment on the fact that the data used in their analysis, which came from the 1993 Survey of Training and Education, were collected at a time when firms and unions alike were being encouraged to embrace enterprise bargaining. The small union wage effect reported in Miller and Mulvey (1996) is, therefore, perhaps surprising given that more decentralised wage structures should provide greater scope for unions to generate a wage mark-up for their members. Of course, coverage by enterprise agreements was far more limited in 1993 than it is today and hence union wage effects when measured across the entire workforce may well have been small. A central premise underlying this article, however, is that in estimating the size of union wage effects it is inappropriate to focus on the workforce as a whole. Instead, workplaces with agreements need to be distinguished from those without them. 
The issue of union wage effects in Australia is revisited in this article. It is argued that previous research has understated the potential for unions to raise member wages by focusing on differences across individuals rather than differences across bargaining units. Unions obtain wage increases by bargaining collectively and hence union wage effects are likely to emerge across workplaces and firms (and industries) rather than within them. A better test of the impact of unions on wages, especially in an environment where enterprise-level bargaining is pervasive, requires data on the wages and characteristics of individual workers that can then be linked to characteristics of the firms and workplaces at which those workers are employed and, most important of all, to the features of union and bargaining activity.

This article reports on an analysis of such data collected as part of the 1995 Australian Workplace Industrial Relations Survey (AWIRS). The results indicate that while there is only a very small intra-workplace union wage effect, differences across workplaces are often considerable. Specifically, it is found that at those workplaces where the majority of workers are covered by collective agreements, a strong union presence confers a wage advantage in the order of 15 to 17 per cent (to members and non-members alike). In contrast, union wage effects are small and insignificant at workplaces where collective agreements have not been negotiated.

\section{Unions, Wage Bargaining and Previous Research}

The conventional approach to the estimation of union wage effects, at least since large survey-based micro-data sets have become available, begins with an equation of the form:

$$
\ln \mathrm{W}_{\mathrm{i}}=\alpha+\beta \mathrm{X}_{\mathrm{i}}+\delta \mathrm{U}_{\mathrm{i}}+\varepsilon_{\mathrm{i}}
$$

where $\mathrm{W}_{\mathrm{i}}$ is the wage of worker $\mathrm{i}, \mathrm{X}_{\mathrm{i}}$ is a vector of worker $\mathrm{i}$ 's characteristics, $\mathrm{U}_{\mathrm{i}}$ is a dichotomous variable indicating whether worker $\mathrm{i}$ is a union member or not, and $\varepsilon_{\mathrm{i}}$ is a 
disturbance term. On the assumption that the earnings determination process does not vary with union membership status, the parameter $\delta$ provides an estimate of the size of the union wage effect.

Alternatively, relaxing the assumption that the earnings determination process must be identical for union and non-union workers requires the separate estimation of wage equations for both union and non-union workers, from which the mean wage differential between union and non-union members can be calculated. As discussed in Booth (1995), who provides an exhaustive survey of the UK evidence, this latter approach has come to dominate empirical research into union wage effects. Miller and Mulvey (1996), however, are an exception here, preferring instead the single equation approach, presumably because of their interest in the effects of omitted variables. For ease of exposition, the approach used in the present study also involves a single equation. As it turns out, the restriction implied in this approach is not violated - the estimated coefficients do not vary much with whether an individual is a union member or not. Instead, what matters is whether the workplace at which the individual works is actively unionised or not.

Australian studies are reviewed by Miller and Mulvey (1993) and, with the exception of a study by Hatton and Chapman (1989) and, of course, the subsequent study by Miller and Mulvey (1996), report positive significant union wage effects which lie in the range of 5 to 15 per cent. The studies by Hatton and Chapman (1989) and Miller and Mulvey (1996), on the other hand, suggest that the union wage differential in Australia may be extremely small, if not zero. As argued by Miller and Mulvey (1996), this reflects the inclusion of a wider array of control variables in these two studies, and in particular, the inclusion of controls for workplace size.

A major problem with this body of research, however, is that the data used typically only allow wages to be affected by individual union membership status, and not by the degree of union coverage or activity within the bargaining group to which the individual worker 
belongs (Booth, 1995, p. 162). This is problematic, especially in studies which include controls for firm and workplace characteristics, as both Hatton and Chapman (1989) and Miller and Mulvey (1996) do. That is, part of the explanation for why larger workplaces pay higher wages may be that larger workplaces are much more likely to be strongly unionised. It thus would be desirable for research to better isolate the effect of unions in contributing to differences in wages across workplaces.

Moreover, there are good reasons to believe that the significance of these across-workplace effects in Australia are likely to have increased in recent years as result of the shift away from reliance on industry-based awards as the principal mechanism of wage determination, towards greater use of enterprise-based (or workplace-based) agreements. Throughout most of the past century, and certainly during the 1980s, the principal mechanism for achieving wage increases in Australia were awards, and as Miller and Mulvey (1996, p. 138) observed, 'industrial law requires that the terms of awards apply to union and non-union employees alike'. ${ }^{2}$ Consequently, union negotiated increases in award wages would automatically flow on to non-union workers also covered by that award - any differences across workplaces in union wage effects were unlikely to reflect workplace union activity and more likely to reflect differences in award coverage.

However, and as discussed in Hawke and Wooden (1998), the 1990s have witnessed major changes in the structures and processes that underpin industrial relations arrangements in Australia. The most obvious manifestation of this change has been the shift towards more decentralised systems for formal bargaining arrangements. This has involved both a move towards enterprise and workplace-level collective agreements, typically covered by the term enterprise bargaining, and, since 1996 at least, increased scope for non-collective or individual agreements. Recent estimates, for example, suggest that by the end of 1998, enterprise agreements (both within the Federal and State jurisdictions) covered around 44 per cent of all Australian employees (see Wooden, 2000, p. 9). Moreover, it is also very clear that these new enterprise agreements have been accompanied by a strong union presence (Hawke 
and Drago, 1998; Wooden, 2000). Indeed, prior to the enactment of the Workplace Relations Act 1996, formal agreement-making processes typically required a union presence in order to be endorsed. Registered non-union agreements, for example, only became possible in 1994, following the introduction of Enterprise Flexibility Agreements, very few of which were ever ratified. ${ }^{3}$ The shift towards enterprise bargaining thus made the emergence of sizeable union wage differentials across different enterprises a distinct possibility.

To be fair, unlike previous Australian studies, Miller and Mulvey (1996) were clearly aware of the likelihood of inter-firm union wage effects, and is reflected in their inclusion of a variable measuring the rate of unionisation within the industry in which the individual was employed. Indeed, Miller and Mulvey found that for men, this variable suggested a quite sizeable union wage effect, of almost 3.5 percentage points. ${ }^{4}$ They, however, downplay this result, arguing that the exclusion of this variable has very little effect on the estimated union wage premium attached to individuals. This is hardly surprising given that Miller and Mulvey (1996) also included industry dummies in their specifications. More importantly, an industrylevel variable can only hope to capture union effects that occur at the industry level. Enterprise- (or workplace-) specific differences arising out of enterprise bargaining will not be captured. Indeed, and as noted above, it is possible that part of the explanation for the highly significant workplace size effect found by Miller and Mulvey lies in a positive correlation between size and the likelihood of bargaining. Hawke and Drago (1998), for example, have argued that large firms (and workplaces) are likely to have substantial resources to devote to the bargaining process, increasing the probability of negotiating successful enterprise agreements. Strong support for this hypothesis was found in AWIRS data.

Ultimately, isolating the across-workplace effects of unions on wages cannot be achieved using individual-level data. Instead, data are required that match individual workers to the firms and workplaces at which they work. ${ }^{5}$ To the best of my knowledge, no previous study of union wage differentials, either in Australia or overseas, has used data of this type. 
To summarise, estimating the size of the union wage differential requires distinguishing not just between individual union members and non-members, but between unionised and non-unionised workplaces. Moreover, the wage effects of unions also need to be allowed to vary according to the strength of union organisation at the workplace and whether the union has entered into collective negotiations with management. In other words, the mere presence of a union member is not sufficient to guarantee a union wage effect. Instead, for a union to be successful in obtaining wage gains for its membership at the enterprise level, requires that the union is both well organised and active within the workplace.

\section{Data and Method}

\section{(i) The AWIRS Data}

Described in more detail in Morehead et al. (1997), the 1995 AWIRS was the second large-scale workplace survey conducted by the Australian federal government for the purpose of providing 'a comprehensive and statistically reliable database on workplace relations in Australia' (Morehead et al., 1997, p. 1). As with the earlier survey, conducted in 1989/90, the 1995 AWIRS was designed to provide a representative sample of all Australian workplaces with two notable exceptions. Workplaces in the agriculture, forestry and fishing and defence industries were out of scope as were workplaces with fewer than five employees. In addition, in this research, workplaces with 5 to 19 employees are ignored since no data were collected from employees at these small workplaces. In total, the sample used in this study represents approximately 37,200 workplaces collectively employing 3.6 million people, or just over onehalf of all Australian employees (Morehead et al., 1997, p. 26).

At each of these workplaces with 20 or more employees, data were collected from both management and from a random sample of employees. In total, 2004 workplaces participated 
in the survey, with permission to survey employees granted at 1896 of these. Just over 30,000 questionnaires were distributed to employees, with 19,155 returned in a form suitable for analysis. Purging the data set for any observations with missing data on any of the variables of interest, however, saw the size of the final data set used in the main analysis decline to 11,840 individuals from 1357 different workplaces. ${ }^{6}$

\section{(ii) Specification and Estimation Method}

As noted earlier, the conventional approach to the estimation of union wage effects when using individual-level data involves a log wage equation of the form specified in equation (1). The availability of data matching employees to workplace and firm characteristics, however, enables the estimation of a more complete specification, as follows:

$$
\begin{aligned}
& \ln \mathrm{W}_{\mathrm{ik}}=\alpha+\beta \mathrm{X}_{\mathrm{ik}}+\delta \mathrm{U}_{\mathrm{ik}}+\phi \mathrm{Z}_{\mathrm{k}}+\varepsilon_{\mathrm{ik}} \\
& \mathrm{i}=1, \ldots \ldots, \mathrm{N}_{\mathrm{k}} \quad \mathrm{k}=1, \ldots \ldots . ., \mathrm{K}
\end{aligned}
$$

where $Z_{k}$ is a set of characteristics describing the workplace (and firm) at which the individual is employed (and includes measures of union bargaining power at the workplace), $\mathrm{N}_{\mathrm{k}}$ is the number of observations for workplace $\mathrm{k}$, and $\mathrm{K}$ is the number of workplaces.

Estimation of equation (2) by ordinary least squares (OLS), however, involves the assumption that the disturbances are independently distributed. As discussed in Wooden and Bora (1999), this assumption might be appropriate in a sample where individuals are randomly selected from a general household population, but not in the AWIRS employee sample where groups of workers have been selected from workplaces, which in turn were selected from the larger population of workplaces. Individuals from the same workplace can be expected to have characteristics that are more similar than individuals drawn from different workplaces, and given that not all of these characteristics will be measurable, it 
follows that there is likely to be correlation between disturbances, violating the assumption of independence.

A more appropriate error structure is given by:

$$
\varepsilon_{\mathrm{ik}}=\mu_{\mathrm{ik}}+\lambda_{\mathrm{k}}
$$

This error term consists of two components. The first component $\left(\mu_{\mathrm{ik}}\right)$ has the usual classical properties, varying independently across individuals both within and across workplaces. The second component $\left(\lambda_{\mathrm{k}}\right)$, on the other hand, varies across workplaces but is constant for workers within the same workplace. Thus, all disturbances have the variance:

$$
\operatorname{Var}\left[\mu_{\mathrm{ik}}+\lambda_{\mathrm{k}}\right]=\sigma^{2}=\sigma^{2} \mu+\sigma^{2} \lambda
$$

But for a given $\mathrm{k}$, the errors for different individuals are correlated because of their common component, $\lambda_{\mathrm{k}}$ :

$$
\operatorname{Corr}\left[\mu_{\mathrm{ik}}+\lambda_{\mathrm{k}}, \mu_{\mathrm{jk}}+\lambda_{\mathrm{k}}\right]=\rho=\sigma^{2}{ }_{\mu} / \sigma^{2}
$$

This error structure describes the random effects model (typically used when dealing with panel data). The efficient estimator is feasible generalised least squares (GLS).

In this analysis, results from using both OLS and GLS (i.e, random effects) estimators are reported. All analyses are conducted using unweighted data. As is conventional, separate equations are estimated for men and women. In addition, to allow for the expected difference in the size of union wage effects depending on the presence or absence of enterprise-level (or workplace-level) bargaining, the sample is, in a subsequent analysis, further separated according to whether or not there are any written collective agreements operating at the workplace which have been specially negotiated for the workplace or firm. ${ }^{7}$ 
The wage variable used in this analysis is usual gross (pre-tax) pay per week divided by usual hours actually worked each week. Unfortunately, measurement error is introduced as a result of the pay data (but not the hours data) being grouped. The conventional response to this problem, and the one used here, is to approximate actual pay by the mid-point within each category (there are a total of 23 pay categories). ${ }^{8}$ The problem of measurement error, of course, remains.

\section{(iv) Explanatory Variables}

The vector $\mathrm{X}_{\mathrm{ij}}$ is comprised of the usual array of human capital variables, demographic characteristics and job characteristics. Specifically, it consists of: seven age-group dummies; seven education dummies; job tenure (specified in quadratic form); a dummy variable for whether disabled; a dummy variable for whether a language other than English is usually spoken at home; the number of dependent children interacted with the age of those children; two dummies for employment status (identifying persons employed on a 'casual' basis and on fixed-term contracts); a race dummy (identifying Australian Aboriginals and Torres Strait Islanders); two region of birth dummies; and seven occupation dummies. This list of individual-level variables is very similar to that used in Miller and Mulvey (1996), with the exceptions that there are no available measures of occupation-specific experience and computer use at work in these data. On the other hand, in contrast to the specification estimated by Miller and Mulvey, the AWIRS data permit the inclusion of variables identifying disability and Aboriginality. More detailed descriptions of these variables, along with summary statistics, are provided in a Data Appendix.

$\mathrm{U}_{\mathrm{ij}}$ is again represented by a dichotomous variable identifying whether the employee was currently a union member. Of greater significance, also included are measures of union organisation at the workplace level. The most obvious variable to represent union power 
within the workplace is the workplace unionisation rate. As Drago and Wooden (1991) have argued with respect to the impact of unions on quits, however, it cannot be automatically presumed that the presence of union members implies the exercise of union influence at the workplace. Instead, what is needed are more direct measures of union activity. In this analysis the degree of union influence at the workplace is captured by interacting the workplace unionisation rate with a simple binary variable indicating the presence of an 'active union'. Created by the AWIRS team (see Morehead et al., 1997, p. 326), this latter variable assumes that a workplace is actively unionised if the senior delegate from the union with most members spends one hour or more each week on union activities, and either a general meeting of members is held at least once every six months, a joint or single union committee exists and meets regularly with management, or delegates meet with management (above first-line supervisor level) at least once a month.

Note that as expected, the degree of correlation between individual union membership status and both the rate of workplace unionisation and the presence of an active union is far from perfect in the data used here (simple correlation coefficients of 0.58 and 0.24 respectively). Further, while the average rate of unionisation is higher at workplaces with active unions than those where the unions present are classified as non-active (68 per cent compared with 60 per cent in weighted workplace-level data), the difference is not large, providing strong support for the contention that union membership need not imply the presence of union activity.

With respect to other workplace and firm-specific controls to be included in $Z_{j}$, the most obvious candidates are measures of workplace and firm size, the labour-capital ratio, product market characteristics, the skill and gender composition of the workforce, and location.

As Miller and Mulvey (1996) note, a positive relationship between firm and/or workplace size and wages is a well established result, even after controlling for occupation and other worker characteristics (see also, Mellow, 1982; Garen, 1985; Brown and Medoff, 1989; Idson 
and Feaster, 1990; Morissette, 1993). Such findings are typically argued to be consistent with efficiency wage theories, given monitoring costs rise with firm size. The greater importance of firm-specific human capital (i.e., training) and greater reliance on teamwork within large firms have also been invoked as explanations for the observed wage premium for working in large firms (Morissette, 1993). In this analysis, separate controls for both workplace size and firm size (five dummy variables) are included. In addition, dummy variables indicating whether the workplace is part of a majority or minority foreign-owned firm may also capture size effects given the firm size dummies only represent total levels of employment of the firm within Australia. That said, other research has found evidence of positive wage effects from foreign ownership that appear to be independent of any size effect (e.g., Globerman, Ries and Vertinsky, 1994; Aitken, Harrison and Lipsey, 1996).

Capital intensity is also widely presumed to influence wage outcomes given capital and skills are complements in production (Hamermesh, 1980), and firm-specific skills are typically not well measured. Unfortunately, in these data no direct measure of capital is available. Instead, the effects of the capital labour ratio are represented with a measure of labour intensity (labour costs as a proportion of total costs).

Another potential source of workplace wage differentials is the presence of monopoly rents. As noted by Groshen (1991, p. 373), the size of wage settlements between employers and employees should reflect the size of the available rents, suggesting a role for measures of the degree of competition in product markets. In the absence of measures of industry concentration ratios (which are only available for the manufacturing and mining industries), the influence of product market competition is represented by two crude dummy variables indicating whether the primary market in which the firm operates has 'a few' or 'many' competitors, with the reference group being no competitors. The relevant question from which this measure was constructed, however, was only asked at workplaces operating on a commercial basis (i.e., for a profit). Workplaces operating on a non-commercial basis have, therefore, been treated as monopolists. A separate dummy variable identifying non- 
commercial workplaces is included to control for any additional differences between these workplaces and commercial workplaces facing non-competitive markets.

Dummy variables are also included to identify workplaces producing primarily for the export market and those which face import competition for their main output. Recent US research has demonstrated that exporters tend to be more productive and pay higher wages (Gaston and Trefler, 1994; Bernard and Jensen, 1995), suggesting the possibility that to succeed in international markets requires operating on a higher production frontier. The impact of import competition on wages, on the other hand, is ambiguous, and presumably will depend on whether the imports are sourced from low- or high-wage economies and on the extent to which local producers are protected from import competition through tariff barriers and the like. ${ }^{9}$

Also included in $\mathrm{Z}_{\mathrm{j}}$ are variables measuring the incidence of shift working and female employment as a proportion of total employment. Shift working is usually thought to be a negative work condition requiring a compensating differential. Further, in many awards and agreements, wage premiums for some types of shift work (e.g., evening shifts) are specified. A measure of the sex composition of the workforce, on the other hand, is included to capture any effects from gender-based discrimination in employment policies. Consistent with US research (e.g., Carrington and Troske, 1998), the coefficient on this variable is expected to be negatively signed indicating that women tend to be concentrated among low wage employers. $^{10}$

Finally, also included are 13 location dummies, 15 industry dummies and 7 variables measuring the occupational mix of the workforce within each workplace. Inclusion of location controls are typically justified as capturing the effects of differing local labour market conditions, while industry dummies are included to control for other unmeasured differences in workplaces that are industry-specific (such as differences in technology). The occupational composition variables, on the other hand, are included as a crude means of 
controlling for sorting behaviour by firms. For example, firms that employ large numbers of workers in high-skilled occupations may also find it rational to pay wage premiums in order to attract the most able workers within less skilled occupation groups.

Again, definitions for all variables used in the analysis, along with summary statistics, are reported in a Data Appendix.

Experimentation was also undertaken with a number of variables not included in the specifications reported in this article. Included here were measures of workplace age (a proxy for vintage effects), the degree of autonomy workplace management has from higher levels in the organisation, the degree to which management systematically structures its relations with employees, the incidence of technological and organisational change, training requirements of jobs, employee involvement in decision-making, the incidence of retrenchments, and the extent of overtime working. None of these variables exhibited any significant explanatory power and hence were subsequently omitted from the analysis.

\section{Results}

Results from the OLS estimation of a classical regression model and GLS estimation of a random effects model, using the full sample, are reported for both men and women in Table 1. There are a number of preliminary observations that can be made. First, comparison of a simple OLS specification which includes only individual-level variables (not reported here) with a specification which also includes workplace-level variables, reveals that the impact of omitted variables bias on the estimated coefficient on the union membership variable is only of importance within the male sample. Consistent with results reported by both Hatton and Chapman (1989) and Miller and Mulvey (1996), the estimated individual union wage effect for men declined from 3.5 per cent to 1.8 per cent once workplace-level variables are 
included. ${ }^{11}$ Among women, however, the coefficient on the union membership variable is insignificantly different from zero in all specifications.

Second, the expectation that the simple classical specification would be inferior to a random effects specification is supported. There is, for example, clear evidence of withinworkplace correlation in the errors, as reflected in the magnitude of $\rho$. Further, the large values on the Lagrange multiplier statistic, which provides a test of the overall utility of the random effects specification compared with the classical regression model, indicates that the former is preferred.

Third, the magnitude and sign of the coefficients on the control variables are broadly in line with expectations. The results, for example, confirm the importance of human capital, with wages rising with educational attainment and experience. Further, workplace size, which is so critical in the analysis of Miller and Mulvey (1996), exerts the expected positive influence on wages, though the quadratic specification indicates that hourly wages rise with workplace size at a declining rate. Firm size, however, does not appear to be significantly associated with wages, though this may reflect collinearity with workplace size. ${ }^{12}$

Fourth, given the strong evidence of heteroscedasticity (which is to be expected given the grouped nature of the data), the OLS standard errors that are reported have been corrected using the estimator proposed by White (1980). Unfortunately, there is no available counterpart to the White estimator for the one-way random effects model, and hence while the estimated GLS coefficients are not inconsistent, unlike the OLS estimates, the estimated variances are. In the case of the variables of most interest here - the union activity variables - a comparison between the corrected and uncorrected OLS results suggests that the direction of bias is likely to be towards understating their significance.

Returning now to the estimated coefficients reported in Table 1 that bear directly on the issue of union effects, and from here on attention will be restricted to the random effects 
specification, there are four results of interest. First, consistent with the findings of Miller and Mulvey (1996), within-workplace wage differences between union members and non-union members are very small. Indeed, they are so small that they are not significantly different from zero. However, and in contrast to Miller and Mulvey's findings, omitting workplace and firm size has no effect on this conclusion. One possible explanation for this difference might lie in the exclusion of small workplaces from the AWIRS sample. The omission of workplace and firm size, however, does alter the magnitude of the coefficients on the workplace-level unionisation variables implying that, as hypothesised earlier, part of the explanation for the positive relationship between size and wages lies in a positive correlation between size and strength of workplace union organisation.

Second, among men at least, there is clear evidence that employees at workplaces where there is a well organised union presence, as reflected in high levels of union activity and high levels of union coverage, receive a large wage premium. Indeed, where union coverage is complete this premium is 9 per cent. ${ }^{13}$

Third, and as hypothesised, union activity makes a difference. Again focusing on the results for men, if union delegates in the workplace are not very active and there is little interaction between the union and management, then the size of the union wage premium is much smaller - less than half the size it would be in the presence of high levels of union activity (and statistically insignificant).

Fourth, this between-workplace union wage effect appears to be much smaller for women than for men. Indeed, among women the coefficients on the workplace level union activity variables are insignificantly different from zero. Such findings appear to be consistent with arguments that, reflecting their historical roots in male-dominated occupations, the continued dominance of men in internal union hierarchies, and the relatively low levels of union activism among women workers (see Pocock 1995), unions have been more effective in securing wage gains for men than women. ${ }^{14}$ 
A guide to the overall magnitude of the union wage effects, when summing across both individual-level and workplace-level variables, is provided in column (1) of Table 2. Under the most favourable conditions - 100 per cent unionisation at the workplace plus the presence of at least one 'active' trade union — the union wage effect ranges from 5.1 per cent for women up to 9.6 per cent for men. The average rate of unionisation at those workplaces with union members, however, is closer to 60 per cent. At this more average workplace, and still assuming the presence of an active trade union, the union wage effect ranges from 3.5 per cent to 6.0 per cent. Finally, if average rates of unionisation are combined with the absence of an active trade union, ${ }^{15}$ then the union wage premium is quite small, varying from just 1.0 per cent to 3.1 per cent, and of course, the statistical power of these effects is very poor.

The next stage of the analysis involved identifying to what extent union wage effects can be attributed to enterprise (and workplace) bargaining. The sample was thus split into two sub-samples depending on the presence or absence of a written collective agreement, and the random effects specification re-estimated. The results are summarised in columns (2) and (3) of Table 2. ${ }^{16}$ These results could hardly be any more striking. At the non-bargaining workplaces the coefficients on the workplace unionisation variables are close to zero in the case of men, and are negatively signed in the case of women. Overall, the net union wage effects, even assuming a strong union presence, range from -3.2 per cent for women to 2.2 per cent for men. In contrast, at workplaces with collective agreements in place, union wage effects are substantial. Moreover, at these workplaces women do not fare any worse than men. Thus, the explanation for why the estimated union wage effect in Table 1 was so small for women must be either because female employees are, compared with males, less likely to be working at workplaces which have negotiated enterprise agreements, or because, women fare so poorly relative to men at workplaces where agreements have not been negotiated. ${ }^{17}$ It certainly does not arise as a result of enterprise bargaining delivering inferior outcomes to women. The overall, union wage effect now varies from 12.1 per cent for men to 13.4 per cent for women. Union activity, however, continues to make a large difference, though for 
men at least, the union wage effect is still significantly different from zero even in the absence of an active union.

Finally, the sub-sample of workplaces with collective agreements was further refined to only include those workplaces where a majority of the non-managerial workforce (more than 50 per cent) were covered by those agreements. As expected, and as summarised in column (4), for this group the union wage effect is even larger, ranging as high as 15 to 17 per cent.

\section{Conclusions}

The main message from this research is a very straightforward one - relative union wage effects in Australia are considerable. Such effects, however, do not manifest in wage differences between union members and non members within the same workplace or firm, but in differences across workers from different workplaces with different levels of union activity. Furthermore, given that such effects were only found to be present where enterprisebased (or workplace-based) agreements also exist, it follows that the emergence of this union wage mark-up is a relatively recent phenomenon associated with the gradual spread of enterprise bargaining since the early 1990s. Such findings suggest the possibility that as enterprise and workplace agreements continues to spread, the attractiveness of union membership to workers will be enhanced. While it is true that the potential for free-riding remains, the incentive for free-riding behaviour must surely be reduced under more decentralised bargaining arrangements which make much more obvious to workers the connection between union membership and improved wage outcomes. Whether this increased incentive to join a union, however, will be sufficient to halt, let alone reverse, the slide in union membership rates experienced over the last decade — falling from almost 50 per cent in the late 1970s to just 28 per cent in 1998 — is debateable. Indeed, on the other side of the employment relationship, a widening of the union wage differential will only serve to further 
enhance the incentive for management to adopt strategies intended to encourage the deunionisation of their workforces.

A secondary result of interest concerned the differential effects of unions on the wages of men and women. Consistent, with the conventional wisdom, the union wage effect was found to be substantially larger for men than for women. This, however, was not the result of the ineffectiveness of unions in bargaining on behalf of women workers. Instead, this finding is a function of both a lesser likelihood of women being covered by enterprise agreements and comparatively poor wage outcomes among female workers at unionised workplaces without collective agreements, and who presumably were either reliant on awards or were outside the awards systems altogether.

Finally, there are a number of caveats concerning the approach used, and conclusions reached, in this study that should be noted. First, the results reported do not bear on the issue of the relative efficacy of unions in securing wage increases for their members under different types of bargaining structures. Unions may be just as successful in securing wage increases under more centralised arrangements (e.g., industry-based bargaining over awards) as they are under enterprise-based bargaining structures. The results reported in this article simply demonstrate that the emergence of a substantial differential between the wages of unionists and non-unionists requires more decentralised bargaining structures.

Second, there is the strong possibility of sample selection bias. Enterprise bargaining was still only in its infancy in 1995 when the data used in this study were collected, and it seems entirely possible that it was the strongest unions, with the power to obtain the largest wage increases in a more decentralised bargaining environment, that were the first to negotiate enterprise agreements. Certainly, both union density and the presence of active unions was much greater at workplaces with written collective agreements than those without them. ${ }^{18}$ This suggests that in more recent years other unions may not have been as successful in 
negotiating wage increases for their members, thus implying that re-estimation of the union wage effect with more recent data would result in a much smaller union wage mark-up.

Third, the data used only permit the analysis of union wage effects within workplaces with at least 20 employees. If union wage effects vary across workplaces according to their size, then this will mean the estimated union wage effects will be biased. In what direction that bias will be is unclear, though US research (e.g., Podgursky, 1986; Wunnava and Ewing, 1999) suggests that union wage effects are greatest in small establishments. If also true of Australia, the estimates reported here should understate the size of the union wage effect.

\section{REFERENCES}

Aitken, B., Harrison, A. and Lipsey, R. (1996), 'Wages and Foreign Ownership: A Comparative Study of Mexico, Venezuela, and the United States', Journal of International Economics 40, 345-371.

Bernard, A.B. and Jensen, J.B. (1995), 'Exporters, Jobs, and Wages in U.S. Manufacturing: 1976-1987', Brookings Papers on Economic Activity, 67-112.

Blanchflower, D.G. (1984), 'Union Relative Wage Effects: A Cross-section Analysis Using Establishment Data', British Journal of Industrial Relations 22, 311-332.

Blanchflower, D.G. and Freeman, R.B. (1992), 'Unionism in the US and Other Advanced OECD Countries', Industrial Relations 31, 56-79.

Booth, A.L. (1995), The Economics of the Trade Union, Cambridge University Press, Cambridge.

Brown, C. and Medoff, J. (1989), 'The Employer Size - Wage Effect', Journal of Political Economy 97, 1027-1059.

Callus, R., Morehead, A., Cully, M. and Buchanan, J. (1991), Industrial Relations at Work: The Australian Workplace Industrial Relations Survey, Australian Government Publishing Service, Canberra.

Carrington, W.J. and Troske, K.R. (1998), 'Sex Segregation in U.S. Manufacturing', Industrial and Labor Relations Review 51, 445-464. 
Christie, V.C. (1992), 'Union Wage Effects and the Probability of Union Membership', The Economic Record 68, 43-56.

Crockett, G.C. and Hall, K. (1987), 'Salaried Professionals and Union Membership: An Australian Perspective', Journal of Industrial Relations 29, 49-65.

Department of Employment, Workplace Relations and Small Business [DEWRSB] (1998), Update: Collective Agreement-making Under the Workplace Relations Act, January to June 1998, Commonwealth of Australia, Canberra.

Drago, R. and Wooden, M. (1991), 'Turnover Down Under: Trade Unions and Exit Voice', Journal of Industrial Relations 33, 234-248.

Gale, F. (1990), ‘A Comfortable Kind of Union?’, Australian Quarterly 62, 15-20.

Garen, J. (1985), 'Worker Heterogeneity, Job Screening, and Firm Size', Journal of Political Economy 93, 715-739.

Gaston, N. and Trefler, D. (1994), 'Protection, Trade, and Wages: Evidence from U.S. Manufacturing', Industrial and Labor Relations Review 47, 574-593.

Gill, F. (1994), Overaward Payments: Observed Patterns and their Implications (Industrial Relations Research Series No. 14), Department of Industrial Relations, Canberra.

Globerman, S., Ries, J. and Vertinsky, I. (1994), 'The Economic Performance of Foreign Affiliates in Canada', Canadian Journal of Economics 27, 143-156.

Groshen, E.L. (1991), 'Five Reasons Why Wages Vary Among Employers', Industrial Relations 30, 350-381.

Hamermesh, D.S. (1980), 'Commentary', in J.J. Siegfried (ed.), The Economics of Firm Size, Market Structure and Social Performance, Federal Trade Commission, Washington DC.

Hancock, K. [Chmn] (1985), Australian Industrial Law and Systems: Report of the Committee of Review, AGPS, Canberra.

Hatton, T.J. and Chapman, B. (1989), 'Post-School Training in Australia: 1900-1980', in D. Pope and L. Alston (eds), Australia's Greatest Asset, Federation Press, Sydney.

Hawke, A. and Drago, R. (1998), The Spread of Enterprise Bargaining Under Labor, The Transformation of Australian Industrial Relations Project Discussion Paper Series No. 2, National Institute of Labour Studies, Flinders University of South Australia, Adelaide.

Hawke, A. and Wooden, M. (1998), 'The Changing Face of Australian Industrial Relations', The Economic Record 74, 74-89.

Idson, T.L. and Feaster, D.J. (1990), 'A Selectivity Model of Employer-Size Wage Differentials', Journal of Labor Economics 8, 99-122. 
Kornfeld, R. (1993), 'The Effects of Union Membership on Wages and Employee Benefits: The Case of Australia', Industrial and Labor Relations Review 47, 114-128.

Manning, H. (1994), 'Women and Union Politics in Australia', Policy, Organisation and Society, No. 9, 38-52.

Mellow, W. (1982), 'Employer Size and Wages', The Review of Economics and Statistics 64, 495-504.

Miller, P. and Mulvey, C. (1993), 'What Do Australian Unions Do?', The Economic Record 69, 315-342.

Miller, P.W. and Mulvey, C. (1996), 'Unions, Firm Size and Wages', The Economic Record 72, 138-153.

Miller, P.W., Mulvey, C. and Neo, L.M. (1999), 'Union Wage Effects and the Extent of Organisation', Australian Journal of Labour Economics 3, 65-92.

Miller, P.W. and Rummery, S. (1989), 'Unionism and the Structure of Male Wages in the Youth Labour Market', Journal of Industrial Relations 31, 185-211.

Mulvey, C. (1986), 'Wage Levels: Do Unions Make A Difference?', in J. Niland (ed.), Wage Fixation in Australia, Allen and Unwin, Sydney.

Morehead, A., Steele, M., Alexander, M., Stephen, K. and Duffin, L. (1997), Changes at Work: The 1995 Australian Workplace Industrial Relations Survey, Addison Wesley Longman, South Melbourne.

Morissette, R. (1993), 'Canadian Jobs and Firm Size: Do Smaller Firms Pay Less?', Canadian Journal of Economics 26, 159-174.

Peetz, D. (1998), Unions in a Contrary World: The Future of the Australian Trade Union Movement, Cambridge University Press, Cambridge.

Pocock, B. (1995), 'Gender and Activism in Australian Unions', Journal of Industrial Relations 37, 377-400.

Pocock, B. and Alexander, M. (1999), 'The Price of Feminised Jobs: New Evidence on the Gender Pay Gap in Australia', Labour and Industry 10, 75-100.

Podgursky, M. (1986), 'Unions, Establishment Size, and Intra-Industry Threat Effects', Industrial and Labor Relations Review 39, 277-284.

Rees, D.I. (1993), 'The Effect of Unionization on Faculty Salaries and Compensation: Estimates from the 1980s', Journal of Labor Research 14, 399-422.

Ryan, E. and Prendergast, H. (1982), 'Unions are for Women, Too!', in K. Cole (ed.), Power, Conflict and Control on Australian Trade Unions, Penguin, Ringwood. 
Stewart, M.B. (1987), 'Collective Bargaining Arrangements, Closed Shops and Relative Pay', Economic Journal 100, 1122-1137.

Stewart, M.B. (1995), 'Union Wage Differentials in an Era of Declining Unionization', Oxford Bulletin of Economics and Statistics 57, 143-166.

Verma, A. (1987), 'Union and Nonunion Wages at the Firm Level: A Combined Institutional and Econometric Analysis', Journal of Labor Research 8, 67-83.

White, H. (1980), 'A Heteroskedasticity Consistent Covariance Matrix Estimator and a Direct Test for Heteroskedasticity', Econometrica 48, 817-838.

Wooden, M. (2000), The Transformation of Australian Industrial Relations, Federation Press, Sydney.

Wooden, M. and Bora, B. (1999), 'Workplace Characteristics and their Effects on Wages: Australia Evidence', Australian Economic Papers 38, 276-289.

Wunnava, P.V. and Ewing, B.T. (1999), 'Union-Nonunion Differentials and Establishment Size: Evidence from the NLSY', Journal of Labor Research 20, 177-184. 


\section{FOOTNOTES}

1 Miller and Mulvey (1996) refer to firm size throughout their paper, even though the variable used in their analysis actually relates to size of location (i.e., workplace).

Awards, however, typically only set minimum rates of pay and hence employers have long had the ability to negotiate over-award pay with their workforces (see Hancock, 1985, p. 193). Callus et al. (1991, p. 42), for example, report on the basis of data from the 1989/90 AWIRS that 68 per cent of all workplaces (with 5 or more employees) paid at least some of their employees above the award rate, with 46 per cent of workplaces paying overawards to a majority of their employees. Further, the average overaward payment, at least within the private sector, was almost 16 per cent of the award rate (Gill, 1994, p. 5).

The DEWRSB (1998, p. 16) reported that only 261 applications for an Enterprise Flexibility Agreement (covering 23,200 employees) were ever endorsed.

$4 \quad$ In a subsequent analysis, Miller, Mulvey and Neo (1999) report an interesting twist on this finding, with the predicted inter-industry union wage premia actually inversely correlated with the extent of union coverage within each industry.

5 If within-firm effects are small, as is concluded here, then matched data per se may not be necessary. Instead, establishment-level data will be adequate. A number of studies using data of this type have been undertaken in the UK and the USA (e.g., Blanchflower, 1984; Rees, 1993; Stewart, 1987, 1995; Verma, 1987), but not in Australia.

6 The two main sources of lost observations were: (i) non-response to the Workplace Characteristics Questionnaire (WCQ), which was the source of data used in constructing the gender and occupation composition of employment variables $(8.5 \%$ of the employee sample were from workplaces where the WCQ was not returned); and (ii) the relatively large proportion of workplaces $(18 \%)$ unable to provide an estimate of the number of union members employed at the workplace. 
Such agreements may or may not have been registered with a relevant industrial tribunal or commission. The estimate for the top open-ended category ( $\$ 1150$ or more per week) was obtained, somewhat arbitrarily, by multiplying the estimate for the top close-ended category by 1.5. The results, however, are not sensitive to the method used to estimate earnings for individuals in this category.

$9 \quad$ Gaston and Trefler (1994) report that in US manufacturing, imports have had a small negative wage effect.

10 Empirical research into the role of gender wage differential typically focus not on the segregation of women into low-wage employers, but their segregation into low-wage occupations and industries. While not explicitly accounted for here, such effects are nevertheless controlled for, through the inclusion of occupation and industry dummies. A recent study by Pocock and Alexander (1999) has, using the same data as are used here, attempted to explain the relative contribution of different types of segregation (that is, on the basis of occupation, industry, establishment and even occupations within establishments) to the gender wage differential. And in a fixed effects specification, also not reported here, falls further, to just 0.8 per cent. Re-estimating the specifications after omitting workplace size, however, does not reveal a clear linear relationship between firm size and hourly wages. There is, however, clear evidence of a discontinuity in the relationship for men, with male employees at firms with less than 1000 employees paid significantly less (the estimated differential ranging between 4.3 and 6.8 per cent) than male employees of larger firms. For women, there is still no obvious relationship between firm size and hourly wages.

When the union density and active union variables were included in the specifications separately (i.e., without an interaction term), the overall explanatory power declined. The estimated coefficients and standard errors on the two variables were as follows: 
Men
Workplace unionisation rate
0.054
0.027
Active union
0.036
0.018

Women

Workplace unionisation rate

0.010

Active union

0.031

The relatively poor performance of Australian unions in serving the interests of their female members has been widely commented upon (e.g., Ryan and Prendergast, 1982; Gale, 1990; Manning, 1994; Peetz, 1998).

Weighted estimates from the AWIRS data indicate that only 30 per cent of workplaces with union members have active trade unions present.

Complete results are available, on request, from the author.

The role of differences in agreement coverage, however, should not be overstated. In these data, for example, 51 per cent of female employees were employed at workplaces with a written agreement. This compares with 60 per cent of male employees. After weighting, the mean level of union density in the workplace sample (as distinct from the employee sample) was 56 per cent at workplaces with written agreements and 33 per cent at workplaces without agreements. Similarly, 30 per cent of workplaces with written agreements reported the presence of an active union compared with just 9 per cent of workplaces without any written agreements. 
TABLE 1

OLS and Random Effects Estimates of Log Hourly Wages (standard errors in parentheses)

\begin{tabular}{|c|c|c|c|c|}
\hline \multirow[t]{2}{*}{ Explanatory variable } & \multicolumn{2}{|c|}{ Men } & \multicolumn{2}{|c|}{ Women } \\
\hline & $\begin{array}{c}\text { Classical } \\
\text { regression }\end{array}$ & $\begin{array}{l}\text { Random } \\
\text { effects }\end{array}$ & $\begin{array}{l}\text { Classical } \\
\text { regression }\end{array}$ & $\begin{array}{l}\text { Random } \\
\text { effects }\end{array}$ \\
\hline \multicolumn{5}{|l|}{ Individual level variables } \\
\hline Union member & $\begin{array}{c}0.003 \\
(0.011)\end{array}$ & $\begin{array}{c}0.006 \\
(0.012)\end{array}$ & $\begin{array}{c}0.008 \\
(0.013)\end{array}$ & $\begin{array}{c}0.012 \\
(0.011)\end{array}$ \\
\hline \multicolumn{5}{|l|}{ Age: } \\
\hline $15-20$ & $\begin{array}{l}-0.395^{* *} \\
(0.031)\end{array}$ & $\begin{array}{l}-0.383 * * \\
(0.026)\end{array}$ & $\begin{array}{l}-0.332 * * \\
(0.032)\end{array}$ & $\begin{array}{l}-0.311 * * \\
(0.022)\end{array}$ \\
\hline $21-24$ & $\begin{array}{l}-0.212^{* *} \\
(0.021)\end{array}$ & $\begin{array}{l}-0.196 * * \\
(0.018)\end{array}$ & $\begin{array}{l}-0.161 * * \\
(0.019)\end{array}$ & $\begin{array}{l}-0.146^{* *} \\
(0.017)\end{array}$ \\
\hline $25-29$ & $\begin{array}{l}-0.114 * * \\
(0.016)\end{array}$ & $\begin{array}{l}-0.098 * * \\
(0.015)\end{array}$ & $\begin{array}{l}-0.075^{* *} \\
(0.016)\end{array}$ & $\begin{array}{l}-0.072 * * \\
(0.015)\end{array}$ \\
\hline $30-34$ & $\begin{array}{l}-0.014 \\
(0.015)\end{array}$ & $\begin{array}{l}-0.013 \\
(0.014)\end{array}$ & $\begin{array}{l}-0.003 \\
(0.018)\end{array}$ & $\begin{array}{l}-0.003 \\
(0.015)\end{array}$ \\
\hline $45-49$ & $\begin{array}{c}0.031 * \\
(0.015)\end{array}$ & $\begin{array}{c}0.034^{*} \\
(0.014)\end{array}$ & $\begin{array}{l}-0.016 \\
(0.019)\end{array}$ & $\begin{array}{l}-0.012 \\
(0.015)\end{array}$ \\
\hline $50-54$ & $\begin{array}{l}0.056^{* *} \\
(0.016)\end{array}$ & $\begin{array}{l}0.048 * * \\
(0.017)\end{array}$ & $\begin{array}{c}0.020 \\
(0.021)\end{array}$ & $\begin{array}{c}0.025 \\
(0.018)\end{array}$ \\
\hline $55+$ & $\begin{array}{l}0.053 * * \\
(0.020)\end{array}$ & $\begin{array}{c}0.045^{*} \\
(0.018)\end{array}$ & $\begin{array}{c}0.028 \\
(0.029)\end{array}$ & $\begin{array}{c}0.044 \# \\
(0.024)\end{array}$ \\
\hline \multicolumn{5}{|l|}{ Educational attainment: } \\
\hline Postgraduate qualification & $\begin{array}{l}0.150 * * \\
(0.021)\end{array}$ & $\begin{array}{l}0.149 * * \\
(0.020)\end{array}$ & $\begin{array}{l}0.128 * * \\
(0.024)\end{array}$ & $\begin{array}{l}0.117 * * \\
(0.020)\end{array}$ \\
\hline Degree & $\begin{array}{l}0.093 * * \\
(0.019)\end{array}$ & $\begin{array}{l}0.092 * * \\
(0.017)\end{array}$ & $\begin{array}{c}0.040 * \\
(0.019)\end{array}$ & $\begin{array}{c}0.036^{*} \\
(0.016)\end{array}$ \\
\hline Associate diploma & $\begin{array}{c}0.013 \\
(0.017)\end{array}$ & $\begin{array}{c}0.021 \\
(0.017)\end{array}$ & $\begin{array}{c}0.044^{*} \\
(0.019)\end{array}$ & $\begin{array}{c}0.038 * \\
(0.017)\end{array}$ \\
\hline Skilled vocational qualification & $\begin{array}{c}0.010 \\
(0.015)\end{array}$ & $\begin{array}{c}0.014 \\
(0.015)\end{array}$ & $\begin{array}{c}0.037 \\
(0.027)\end{array}$ & $\begin{array}{c}0.030 \\
(0.022)\end{array}$ \\
\hline Basic vocational qualification & $\begin{array}{c}0.019 \\
(0.032)\end{array}$ & $\begin{array}{c}0.011 \\
(0.026)\end{array}$ & $\begin{array}{l}-0.003 \\
(0.027)\end{array}$ & $\begin{array}{l}-0.009 \\
(0.019)\end{array}$ \\
\hline Some secondary school & $\begin{array}{l}-0.047^{* *} \\
(0.014)\end{array}$ & $\begin{array}{l}-0.042 * * \\
(0.013)\end{array}$ & $\begin{array}{l}-0.029 * \\
(0.014)\end{array}$ & $\begin{array}{l}-0.031 * \\
(0.012)\end{array}$ \\
\hline Primary school & $\begin{array}{l}-0.073 * \\
(0.037)\end{array}$ & $\begin{array}{l}-0.068 * \\
(0.027)\end{array}$ & $\begin{array}{l}-0.031 \\
(0.052)\end{array}$ & $\begin{array}{l}-0.040 \\
(0.032)\end{array}$ \\
\hline Tenure & $\begin{array}{l}0.011 * * \\
(0.002)\end{array}$ & $\begin{array}{l}0.011^{* *} \\
(0.002)\end{array}$ & $\begin{array}{c}0.011 * * \\
(0.003)\end{array}$ & $\begin{array}{l}0.012 * * \\
(0.002)\end{array}$ \\
\hline Tenure squared (x 100) & $\begin{array}{l}-0.027 * * \\
(0.007)\end{array}$ & $\begin{array}{l}-0.023 * * \\
(0.005)\end{array}$ & $\begin{array}{l}-0.037 * * \\
(0.011)\end{array}$ & $\begin{array}{l}-0.038 * * \\
(0.009)\end{array}$ \\
\hline
\end{tabular}


TABLE 1 (CONT'D)

\begin{tabular}{|c|c|c|c|c|}
\hline \multirow[t]{2}{*}{ Explanatory variable } & \multicolumn{2}{|c|}{ Men } & \multicolumn{2}{|c|}{ Women } \\
\hline & $\begin{array}{l}\text { Classical } \\
\text { regression }\end{array}$ & $\begin{array}{l}\text { Random } \\
\text { effects }\end{array}$ & $\begin{array}{l}\text { Classical } \\
\text { regression }\end{array}$ & $\begin{array}{l}\text { Random } \\
\text { effects }\end{array}$ \\
\hline Disabled & $\begin{array}{l}-0.073 * * \\
(0.015)\end{array}$ & $\begin{array}{l}-0.049 * * \\
(0.015)\end{array}$ & $\begin{array}{l}-0.035 \\
(0.024)\end{array}$ & $\begin{array}{l}-0.018 \\
(0.017)\end{array}$ \\
\hline Non-English speaking & $\begin{array}{l}-0.065^{* *} \\
(0.023)\end{array}$ & $\begin{array}{l}-0.065^{* *} \\
(0.021)\end{array}$ & $\begin{array}{l}-0.052 * \\
(0.026)\end{array}$ & $\begin{array}{l}-0.042 * \\
(0.021)\end{array}$ \\
\hline No. of dependent children $<4$ yrs & $\begin{array}{l}0.022 * * \\
(0.008)\end{array}$ & $\begin{array}{l}0.025^{* *} \\
(0.008)\end{array}$ & $\begin{array}{c}0.031 * \\
(0.013)\end{array}$ & $\begin{array}{l}0.034 * * \\
(0.012)\end{array}$ \\
\hline $\begin{array}{l}\text { No. of dependent children 5-12 } \\
\text { yrs }\end{array}$ & $\begin{array}{l}0.022^{* *} \\
(0.006)\end{array}$ & $\begin{array}{l}0.019 * * \\
(0.006)\end{array}$ & $\begin{array}{l}-0.013 \\
(0.009)\end{array}$ & $\begin{array}{l}-0.012 \# \\
(0.007)\end{array}$ \\
\hline No. of dependent children $13+$ yrs & $\begin{array}{l}0.020 * * \\
(0.007)\end{array}$ & $\begin{array}{l}0.020 * * \\
(0.006)\end{array}$ & $\begin{array}{l}-0.022 * \\
(0.009)\end{array}$ & $\begin{array}{l}-0.020 * * \\
(0.007)\end{array}$ \\
\hline Casual employee & $\begin{array}{c}0.053^{*} \\
(0.024)\end{array}$ & $\begin{array}{l}0.051^{* *} \\
(0.019)\end{array}$ & $\begin{array}{l}0.064^{* *} \\
(0.018)\end{array}$ & $\begin{array}{l}0.067 * * \\
(0.015)\end{array}$ \\
\hline Fixed-term contract worker & $\begin{array}{l}-0.033 \\
(0.022)\end{array}$ & $\begin{array}{l}-0.038 * \\
(0.017)\end{array}$ & $\begin{array}{l}-0.046 * \\
(0.020)\end{array}$ & $\begin{array}{l}-0.054 * * \\
(0.016)\end{array}$ \\
\hline Race / Country of birth dummies & YES & YES & YES & YES \\
\hline Occupation dummies & YES & YES & YES & YES \\
\hline \multicolumn{5}{|l|}{ Workplace level variables } \\
\hline Unionisation $\mathrm{x}$ Active union & $\begin{array}{l}0.093 * * \\
(0.020)\end{array}$ & $\begin{array}{l}0.090 * * \\
(0.031)\end{array}$ & $\begin{array}{c}0.033 \\
(0.026)\end{array}$ & $\begin{array}{c}0.039 \\
(0.039)\end{array}$ \\
\hline Unionisation $\mathrm{x}$ (1-Active union) & $\begin{array}{c}0.039 \# \\
(0.021)\end{array}$ & $\begin{array}{c}0.042 \\
(0.030)\end{array}$ & $\begin{array}{c}0.015 \\
(0.022)\end{array}$ & $\begin{array}{l}-0.004 \\
(0.034)\end{array}$ \\
\hline Labour intensity & $\begin{array}{l}-0.018 \\
(0.024)\end{array}$ & $\begin{array}{c}0.005 \\
(0.036)\end{array}$ & $\begin{array}{l}-0.055^{*} \\
(0.027)\end{array}$ & $\begin{array}{l}-0.024 \\
(0.042)\end{array}$ \\
\hline Workplace size $\left(\mathrm{x} 10^{3}\right)$ & $\begin{array}{l}0.157 * * \\
(0.039)\end{array}$ & $\begin{array}{c}0.141^{*} \\
(0.063)\end{array}$ & $\begin{array}{c}0.068 \# \\
(0.040)\end{array}$ & $\begin{array}{c}0.075 \\
(0.070)\end{array}$ \\
\hline Workplace size squared (x 106) & $\begin{array}{l}-0.064 * * \\
(0.024)\end{array}$ & $\begin{array}{l}-0.052 \\
(0.040)\end{array}$ & $\begin{array}{l}-0.016 \\
(0.019)\end{array}$ & $\begin{array}{l}-0.024 \\
(0.039)\end{array}$ \\
\hline \multicolumn{5}{|l|}{ Firm size: } \\
\hline$<100$ employees & $\begin{array}{l}-0.037 * \\
(0.017)\end{array}$ & $\begin{array}{l}-0.039 \\
(0.025)\end{array}$ & $\begin{array}{c}0.016 \\
(0.018)\end{array}$ & $\begin{array}{c}0.013 \\
(0.030)\end{array}$ \\
\hline 100-499 employees & $\begin{array}{l}-0.029 * \\
(0.014)\end{array}$ & $\begin{array}{l}-0.029 \\
(0.022)\end{array}$ & $\begin{array}{c}0.024 \\
(0.017)\end{array}$ & $\begin{array}{c}0.014 \\
(0.027)\end{array}$ \\
\hline 500-999 employees & $\begin{array}{l}-0.065^{* *} \\
(0.016)\end{array}$ & $\begin{array}{l}-0.067 * * \\
(0.026)\end{array}$ & $\begin{array}{l}-0.006 \\
(0.019)\end{array}$ & $\begin{array}{l}-0.006 \\
(0.033)\end{array}$ \\
\hline 10000-19999 employees & $\begin{array}{c}0.019 \\
(0.019)\end{array}$ & $\begin{array}{c}0.021 \\
(0.030)\end{array}$ & $\begin{array}{c}0.069 * \\
(0.031)\end{array}$ & $\begin{array}{c}0.053 \\
(0.040)\end{array}$ \\
\hline 20000 employees or more & $\begin{array}{l}-0.038^{*} \\
(0.018)\end{array}$ & $\begin{array}{l}-0.033 \\
(0.029)\end{array}$ & $\begin{array}{c}0.000 \\
(0.017)\end{array}$ & $\begin{array}{l}-0.004 \\
(0.032)\end{array}$ \\
\hline
\end{tabular}


TABLE 1 (CONT'D)

\begin{tabular}{|c|c|c|c|c|}
\hline \multirow[t]{2}{*}{ Explanatory variable } & \multicolumn{2}{|c|}{ Men } & \multicolumn{2}{|c|}{ Women } \\
\hline & $\begin{array}{l}\text { Classical } \\
\text { regression }\end{array}$ & $\begin{array}{l}\text { Random } \\
\text { effects }\end{array}$ & $\begin{array}{l}\text { Classical } \\
\text { regression }\end{array}$ & $\begin{array}{l}\text { Random } \\
\text { effects }\end{array}$ \\
\hline Majority foreign owned & $\begin{array}{l}0.049 * * \\
(0.015)\end{array}$ & $\begin{array}{c}0.044 \# \\
(0.022)\end{array}$ & $\begin{array}{l}0.052 * * \\
(0.019)\end{array}$ & $\begin{array}{c}0.028 \\
(0.029)\end{array}$ \\
\hline Minority foreign owned & $\begin{array}{l}0.049 * * \\
(0.017)\end{array}$ & $\begin{array}{l}0.043 \# \\
(0.025)\end{array}$ & $\begin{array}{l}-0.009 \\
(0.018)\end{array}$ & $\begin{array}{l}-0.012 \\
(0.030)\end{array}$ \\
\hline \multicolumn{5}{|l|}{ No. of competitors: } \\
\hline Few & $\begin{array}{c}0.004 \\
(0.015)\end{array}$ & $\begin{array}{c}0.001 \\
(0.024)\end{array}$ & $\begin{array}{l}-0.014 \\
(0.022)\end{array}$ & $\begin{array}{l}-0.029 \\
(0.031)\end{array}$ \\
\hline Many & $\begin{array}{c}0.012 \\
(0.015)\end{array}$ & $\begin{array}{c}0.002 \\
(0.022)\end{array}$ & $\begin{array}{l}-0.023 \\
(0.017)\end{array}$ & $\begin{array}{l}-0.036 \\
(0.027)\end{array}$ \\
\hline Public & $\begin{array}{c}0.006 \\
(0.017)\end{array}$ & $\begin{array}{c}0.020 \\
(0.028)\end{array}$ & $\begin{array}{c}0.040 * \\
(0.020)\end{array}$ & $\begin{array}{c}0.044 \\
(0.033)\end{array}$ \\
\hline Non-commercial & $\begin{array}{l}-0.049 * \\
(0.022)\end{array}$ & $\begin{array}{l}-0.059 \# \\
(0.033)\end{array}$ & $\begin{array}{l}-0.067 * \\
(0.026)\end{array}$ & $\begin{array}{l}-0.087 * \\
(0.040)\end{array}$ \\
\hline Exporter & $\begin{array}{l}0.113 * * \\
(0.023)\end{array}$ & $\begin{array}{l}0.123^{* *} \\
(0.036)\end{array}$ & $\begin{array}{c}0.032 \\
(0.043)\end{array}$ & $\begin{array}{c}0.084 \\
(0.054)\end{array}$ \\
\hline Import competition & $\begin{array}{l}-0.024 \# \\
(0.014)\end{array}$ & $\begin{array}{l}-0.021 \\
(0.021)\end{array}$ & $\begin{array}{l}-0.017 \\
(0.017)\end{array}$ & $\begin{array}{l}-0.021 \\
(0.026)\end{array}$ \\
\hline$\%$ shift workers & $\begin{array}{l}0.075^{* *} \\
(0.019)\end{array}$ & $\begin{array}{c}0.051 \# \\
(0.027)\end{array}$ & $\begin{array}{c}0.034 \# \\
(0.020)\end{array}$ & $\begin{array}{c}0.035 \\
(0.031)\end{array}$ \\
\hline$\%$ female & $\begin{array}{l}-0.125^{* *} \\
(0.036)\end{array}$ & $\begin{array}{l}-0.109 * \\
(0.047)\end{array}$ & $\begin{array}{l}-0.050 \\
(0.037)\end{array}$ & $\begin{array}{l}-0.108 * \\
(0.052)\end{array}$ \\
\hline Occupational composition & YES & YES & YES & YES \\
\hline Location dummies & YES & YES & YES & YES \\
\hline Industry dummies & YES & YES & YES & YES \\
\hline Constant & $\begin{array}{l}2.611 * * \\
(0.070)\end{array}$ & $\begin{array}{l}2.573 * * \\
(0.094)\end{array}$ & $\begin{array}{l}2.609 * * \\
(0.072)\end{array}$ & $\begin{array}{c}2.606 * * \\
(0.072)\end{array}$ \\
\hline R-squared & \multicolumn{2}{|c|}{0.418} & \multicolumn{2}{|c|}{0.307} \\
\hline Adjusted R-squared & \multicolumn{2}{|c|}{0.411} & \multicolumn{2}{|c|}{0.295} \\
\hline Model F & \multicolumn{2}{|c|}{$54.16^{* *}$} & \multicolumn{2}{|c|}{$24.65 * *$} \\
\hline Breusch-Pagan chi-squared $(\mathrm{df}=\mathrm{k}-1)$ & \multicolumn{2}{|c|}{$1416.93 * *$} & \multicolumn{2}{|c|}{$1548.62 * *$} \\
\hline LM test (REM vs Classical) & \multicolumn{2}{|c|}{$469.97 * *$} & \multicolumn{2}{|c|}{$413.02 * *$} \\
\hline $\begin{array}{l}\text { Within-workplace correlation in } \\
\text { errors }(\rho)\end{array}$ & \multicolumn{2}{|c|}{0.251} & \multicolumn{2}{|c|}{0.393} \\
\hline $\mathrm{N}$ & \multicolumn{2}{|l|}{6804} & \multicolumn{2}{|c|}{5036} \\
\hline
\end{tabular}

Notes: The reported standard errors for the OLS specifications (but not the random effects model) have been corrected for the presence of heteroscedastic error structures.

$* *, *$ and \# indicate significance at the one, five and ten per cent levels, respectively, in a two-tailed test. 
TABLE 2

Summary of Union Wage Effects

\begin{tabular}{|c|c|c|c|c|}
\hline & \multirow[b]{2}{*}{$\begin{array}{c}\text { All } \\
\text { workplaces }\end{array}$} & \multicolumn{3}{|c|}{ Workplaces where: } \\
\hline & & $\begin{array}{l}\text { No written } \\
\text { collective } \\
\text { agreements } \\
\text { present }\end{array}$ & $\begin{array}{l}\text { At least one } \\
\text { collective } \\
\text { agreement } \\
\text { present }\end{array}$ & $\begin{array}{l}\text { Majority of } \\
\text { non- } \\
\text { managerial } \\
\text { employees } \\
\text { covered by } \\
\text { collective } \\
\text { agreements } \\
\text { (4) }\end{array}$ \\
\hline \multicolumn{5}{|l|}{ Men } \\
\hline \multicolumn{5}{|l|}{ Coefficients } \\
\hline Unionisation rate $\mathrm{x}$ Active union & $0.090 * *$ & -0.0005 & $0.126 * *$ & $0.144 * *$ \\
\hline Unionisation rate $\mathrm{x}$ (1-Active union) & 0.042 & -0.003 & $0.088 \#$ & $0.091 \#$ \\
\hline Union member & 0.006 & 0.023 & -0.005 & 0.0008 \\
\hline \multicolumn{5}{|l|}{ Net union wage effect (\%) assuming: } \\
\hline $100 \%$ unionisation + Active union & 9.6 & 2.2 & 12.1 & 14.5 \\
\hline $60 \%$ unionisation + Active union & 6.0 & 2.2 & 7.1 & 8.7 \\
\hline $\begin{array}{l}60 \% \text { unionisation }+ \text { Union not } \\
\text { active }\end{array}$ & 3.1 & 2.1 & 4.8 & 5.5 \\
\hline Number of observations & 6804 & 2524 & 4280 & 3558 \\
\hline \multicolumn{5}{|l|}{ Women } \\
\hline \multicolumn{5}{|l|}{ Coefficients } \\
\hline Unionisation rate $\mathrm{x}$ Active union & 0.039 & -0.065 & $0.134 *$ & $0.167 * *$ \\
\hline Unionisation rate $\mathrm{x}$ (1-Active union) & -0.004 & -0.036 & 0.047 & 0.078 \\
\hline Union member & 0.012 & 0.033 & -0.0001 & -0.001 \\
\hline \multicolumn{5}{|l|}{ Net union wage effect (\%) assuming: } \\
\hline $100 \%$ unionisation + Active union & 5.1 & -3.2 & 13.4 & 16.6 \\
\hline $60 \%$ unionisation + Active union & 3.5 & -0.6 & 8.0 & 9.9 \\
\hline $\begin{array}{l}60 \% \text { unionisation }+ \text { Union not } \\
\text { active }\end{array}$ & 1.0 & 1.1 & 2.8 & 4.6 \\
\hline Number of observations & 5036 & 2431 & 2605 & 1996 \\
\hline
\end{tabular}

Note: $\quad * *$ and $*$ indicate significance at the one and five per cent levels, respectively, in a two-tailed test. 
DATA APPENDIX

Variable Definitions and Means

(all data are unweighted)

\begin{tabular}{|c|c|c|c|}
\hline \multirow[t]{2}{*}{ Variable } & \multirow[t]{2}{*}{ Definition } & \multicolumn{2}{|c|}{ Means } \\
\hline & & $\begin{array}{c}\text { Men } \\
(\mathrm{N}=6804)\end{array}$ & $\begin{array}{c}\text { Women } \\
(\mathrm{N}=5036)\end{array}$ \\
\hline
\end{tabular}

Hourly pay

Gross pay per week (\$) divided by

hours actually worked each week

18.06

14.85

Individual level variables

Union member

Dummy variable: Equals 1 if a member of a trade union

0.55

0.44

Age:

15-20

21-24

25-29

30-34

35-44 [reference

group]

45-49

50-54

$55+$

Educational attainment:

Postgraduate

qualification

Degree

Associate diploma

Skilled vocational qualification

Basic vocational qualification
Dummy variable: Equals 1 if aged between 15 and 20 years

$0.05 \quad 0.08$

Dummy variable: Equals 1 if aged between 21 and 24 years

Dummy variable: Equals 1 if aged between 25 and 29 years

Dummy variable: Equals 1 if aged between 30 and 34 years

Dummy variable: Equals 1 if aged between 35 and 44 years

Dummy variable: Equals 1 if aged between 45 and 49 years

$0.08 \quad 0.12$

$0.12 \quad 0.16$

$0.15 \quad 0.14$

$0.31 \quad 0.26$

$0.13 \quad 0.12$

$0.09 \quad 0.08$

50 and 54 years

Dummy variable: Equals 1 if aged 55 years or older

$0.08 \quad 0.04$

Dummy variable: Equals 1 if highest

education level is postgraduate degree or

diploma

$0.08 \quad 0.08$

Dummy variable: Equals 1 if highest

education level is undergraduate degree or

diploma

$0.13 \quad 0.14$

Dummy variable: Equals 1 if highest

education level is associate diploma /

advanced certificate

$0.09 \quad 0.09$

Dummy variable: Equals 1 if highest

education level is skilled vocational

qualification

$0.18 \quad 0.05$

Dummy variable: Equals 1 if highest

education level is basic vocational

qualification 


\begin{tabular}{|c|c|c|c|}
\hline \multirow[t]{2}{*}{ Variable } & \multirow[t]{2}{*}{ Definition } & \multicolumn{2}{|c|}{ Means } \\
\hline & & Men & Women \\
\hline $\begin{array}{l}\text { Completed } \\
\text { secondary school } \\
\text { [reference group] }\end{array}$ & $\begin{array}{l}\text { Dummy variable: Equals } 1 \text { if completed } \\
\text { secondary school and have not obtained higher } \\
\text { qualification }\end{array}$ & 0.18 & 0.22 \\
\hline $\begin{array}{l}\text { Some secondary } \\
\text { school }\end{array}$ & $\begin{array}{l}\text { Dummy variable: Equals } 1 \text { if attended secondary } \\
\text { school but did not complete }\end{array}$ & 0.27 & 0.32 \\
\hline Primary school & $\begin{array}{l}\text { Dummy variable: Equals } 1 \text { if attended primary } \\
\text { school but not secondary school }\end{array}$ & 0.03 & 0.02 \\
\hline Tenure & Years employed at workplace & 7.25 & 4.97 \\
\hline Disabled & $\begin{array}{l}\text { Dummy variable: Equals } 1 \text { if a health condition } \\
\text { or disability exists which is likely to last for } \\
\text { more than } 6 \text { months }\end{array}$ & 0.08 & 0.07 \\
\hline $\begin{array}{l}\text { Non-English } \\
\text { speaking }\end{array}$ & $\begin{array}{l}\text { Dummy variable: Equals } 1 \text { if usually speaks } \\
\text { language other than English at home }\end{array}$ & 0.06 & 0.07 \\
\hline $\begin{array}{l}\text { No. of dependent } \\
\text { children }<4 \text { yrs }\end{array}$ & Number of dependent children aged 0 to 4 years & 0.25 & 0.11 \\
\hline $\begin{array}{l}\text { No. of dependent } \\
\text { children 5-12 yrs }\end{array}$ & $\begin{array}{l}\text { Number of dependent children aged } 5 \text { to } 12 \\
\text { years }\end{array}$ & 0.39 & 0.26 \\
\hline $\begin{array}{l}\text { No. of dependent } \\
\text { children } 13+\text { yrs }\end{array}$ & $\begin{array}{l}\text { Number of dependent children aged } 13 \text { years } \\
\text { or over }\end{array}$ & 0.32 & 0.27 \\
\hline Aboriginal origin & $\begin{array}{l}\text { Dummy variable: Equals } 1 \text { if of Aboriginal or } \\
\text { Torres Strait Islander origin }\end{array}$ & 0.01 & 0.01 \\
\hline $\begin{array}{l}\text { OS-born - } \\
\text { English-speaking } \\
\text { country }\end{array}$ & $\begin{array}{l}\text { Dummy variable: Equals } 1 \text { if born overseas in } \\
\text { one of the main English-speaking countries } \\
\text { (UK, Ireland, Canada, South Africa or USA) }\end{array}$ & 0.12 & 0.10 \\
\hline $\begin{array}{l}\text { OS-born - non- } \\
\text { English-speaking } \\
\text { country }\end{array}$ & $\begin{array}{l}\text { Dummy variable: Equals } 1 \text { if born overseas but } \\
\text { not in one of the main English-speaking } \\
\text { countries }\end{array}$ & 0.12 & 0.13 \\
\hline Casual employee & $\begin{array}{l}\text { Dummy variable: Equals } 1 \text { if not entitled to both } \\
\text { paid holiday leave or paid sick leave }\end{array}$ & 0.07 & 0.15 \\
\hline $\begin{array}{l}\text { Fixed-term contract } \\
\text { worker }\end{array}$ & $\begin{array}{l}\text { Dummy variable: Equals } 1 \text { if employment } \\
\text { contracts ends on a particular date }\end{array}$ & 0.07 & 0.08 \\
\hline Occupation: & & & \\
\hline Managers & $\begin{array}{l}\text { Dummy variable: Equals } 1 \text { if employed in } \\
\text { occupation group, Managers }\end{array}$ & 0.12 & 0.05 \\
\hline Professionals & $\begin{array}{l}\text { Dummy variable: Equals } 1 \text { if employed in } \\
\text { occupation group, Professionals }\end{array}$ & 0.15 & 0.13 \\
\hline Para-professionals & $\begin{array}{l}\text { Dummy variable: Equals } 1 \text { if employed in } \\
\text { occupation group, Para-professionals }\end{array}$ & 0.11 & 0.08 \\
\hline Tradespersons & $\begin{array}{l}\text { Dummy variable: Equals } 1 \text { if employed in } \\
\text { occupation group, Tradespersons \& Apprentices }\end{array}$ & 0.16 & 0.01 \\
\hline
\end{tabular}




\begin{tabular}{|c|c|c|c|}
\hline \multirow[t]{2}{*}{ Variable } & \multirow[t]{2}{*}{ Definition } & \multicolumn{2}{|c|}{ Means } \\
\hline & & Men & Women \\
\hline Clerks & $\begin{array}{l}\text { Dummy variable: Equals } 1 \text { if employed in } \\
\text { occupation group, Clerks }\end{array}$ & 0.10 & 0.36 \\
\hline $\begin{array}{l}\text { Sales and } \\
\text { personal service }\end{array}$ & $\begin{array}{l}\text { Dummy variable: Equals } 1 \text { if employed in } \\
\text { occupation group, Sales \& Personal Service } \\
\text { Workers }\end{array}$ & 0.07 & 0.21 \\
\hline $\begin{array}{l}\text { Plant \& machine } \\
\text { operators \& drivers }\end{array}$ & $\begin{array}{l}\text { Dummy variable: Equals } 1 \text { if employed in } \\
\text { occupation group, Plant \& Machine Operators } \\
\text { \& Drivers }\end{array}$ & 0.17 & 0.05 \\
\hline $\begin{array}{l}\text { Labourers [reference } \\
\text { group] }\end{array}$ & $\begin{array}{l}\text { Dummy variable: Equals } 1 \text { if employed in } \\
\text { occupation group, Labourers \& Related } \\
\text { Workers }\end{array}$ & 0.14 & 0.12 \\
\hline \multicolumn{4}{|l|}{ Workplace level variables } \\
\hline Unionisation & $\begin{array}{l}\text { Proportion of employees at the workplace who } \\
\text { are members of a trade union }\end{array}$ & 0.54 & 0.47 \\
\hline Active union & $\begin{array}{l}\text { Dummy variable: Equals } 1 \text { if the senior } \\
\text { delegate from the union with most members } \\
\text { spends one hour or more each week on union } \\
\text { activities, and either a general meeting of } \\
\text { members is held at least once every six } \\
\text { months, a union committee exists and meets } \\
\text { regularly with management, or delegates meet } \\
\text { with management at least once a month. }\end{array}$ & 0.43 & 0.30 \\
\hline Labour intensity & Labour costs as a proportion of total costs & 0.46 & 0.50 \\
\hline Workplace size & $\begin{array}{l}\text { Total number of employees working at or from } \\
\text { workplace during pay period ended on or } \\
\text { before } 18 \text { August } 1995\end{array}$ & 245.8 & 274.7 \\
\hline \multicolumn{4}{|l|}{ Firm size: } \\
\hline$<100$ employees & $\begin{array}{l}\text { Dummy variable: Equals } 1 \text { if less than } 100 \\
\text { employees work for organisation }\end{array}$ & 0.17 & 0.17 \\
\hline 100-499 employees & $\begin{array}{l}\text { Dummy variable: Equals } 1 \text { if between } 100 \text { and } \\
499 \text { employees work for organisation }\end{array}$ & 0.23 & 0.21 \\
\hline 500-999 employees & $\begin{array}{l}\text { Dummy variable: Equals } 1 \text { if between } 500 \text { and } \\
999 \text { employees work for organisation }\end{array}$ & 0.11 & 0.10 \\
\hline $\begin{array}{l}\text { 1000-9999 employees } \\
\text { [reference group] }\end{array}$ & $\begin{array}{l}\text { Dummy variable: Equals } 1 \text { if between } 1000 \\
\text { and } 9999 \text { employees work for organisation }\end{array}$ & 0.29 & 0.24 \\
\hline $\begin{array}{l}\text { 10000-19999 } \\
\text { employees }\end{array}$ & $\begin{array}{l}\text { Dummy variable: Equals } 1 \text { if between } 10000 \\
\text { and } 19999 \text { employees work for organisation }\end{array}$ & 0.08 & 0.06 \\
\hline $\begin{array}{l}20000 \text { employees or } \\
\text { more }\end{array}$ & $\begin{array}{l}\text { Dummy variable: Equals } 1 \text { if } 20000 \text { employees } \\
\text { or more work for organisation }\end{array}$ & 0.11 & 0.21 \\
\hline $\begin{array}{l}\text { Majority foreign } \\
\text { owned }\end{array}$ & $\begin{array}{l}\text { Dummy variable: Equals } 1 \text { if firm } \\
\text { predominantly or wholly foreign owned }\end{array}$ & 0.18 & 0.13 \\
\hline
\end{tabular}




\begin{tabular}{|c|c|c|c|}
\hline \multirow[t]{2}{*}{ Variable } & \multirow[t]{2}{*}{ Definition } & \multicolumn{2}{|c|}{ Means } \\
\hline & & Men & Women \\
\hline $\begin{array}{l}\text { Minority foreign } \\
\text { owned }\end{array}$ & $\begin{array}{l}\text { Dummy variable: Equals } 1 \text { if between } \\
1 \text { and } 50 \text { per cent of the firm is foreign owned }\end{array}$ & 0.12 & 0.12 \\
\hline No. of competitors: & & & \\
\hline $\begin{array}{l}\text { None [reference } \\
\text { group] }\end{array}$ & $\begin{array}{l}\text { Dummy variable: Equals } 1 \text { if there are no } \\
\text { competitors for this workplace's major product } \\
\text { or service }\end{array}$ & 0.47 & 0.49 \\
\hline Few & $\begin{array}{l}\text { Dummy variable: Equals } 1 \text { if there are few } \\
\text { competitors for this workplace's major product } \\
\text { or service }\end{array}$ & 0.20 & 0.14 \\
\hline Many & $\begin{array}{l}\text { Dummy variable: Equals } 1 \text { if there are many } \\
\text { competitors for this workplace's major product } \\
\text { or service }\end{array}$ & 0.33 & 0.37 \\
\hline Non-commercial & $\begin{array}{l}\text { Dummy variable: Equals } 1 \text { if workplace does } \\
\text { not undertake activity for the purpose of making } \\
\text { a profit }\end{array}$ & 0.24 & 0.29 \\
\hline Exporter & $\begin{array}{l}\text { Dummy variable: Equals } 1 \text { if more than } 50 \text { per } \\
\text { cent of workplace's major product or service is } \\
\text { exported }\end{array}$ & 0.06 & 0.02 \\
\hline Import competition & $\begin{array}{l}\text { Dummy variable: Equals } 1 \text { if workplace faces } \\
\text { import competition for its major product or } \\
\text { service }\end{array}$ & 0.25 & 0.19 \\
\hline$\%$ shift workers & $\begin{array}{l}\text { Proportion of employees who work shifts or } \\
\text { are on call }\end{array}$ & 0.30 & 0.29 \\
\hline$\%$ female & Share of females in total workplace employment & 0.29 & 0.56 \\
\hline
\end{tabular}

Note: Though not reported above, the data set used in the analysis also included 15 industry dummies, 13 location dummies and a set of 7 variables measuring the occupational composition of the workforce. 


\section{University Library}

\section{- M M I N E R VA A gateway to Melbourne's research publications}

Minerva Access is the Institutional Repository of The University of Melbourne

Author/s:

Wooden, M

Title:

Union wage effects in the presence of enterprise bargaining

Date:

2001-03-01

Citation:

Wooden, M. (2001). Union wage effects in the presence of enterprise bargaining.

ECONOMIC RECORD, 77 (236), pp.1-18. https://doi.org/10.1111/1475-4932.00001.

Persistent Link:

http://hdl.handle.net/11343/33635 